\title{
Cis-regulatory hairpin-shaped mRNA encoding a reporter protein: catalytic sensing of nucleic acid sequence at single nucleotide resolution
}

\author{
Atsushi Narita, Kazumasa Ogawa, Shinsuke Sando \& Yasuhiro Aoyama \\ Department of Synthetic Chemistry and Biological Chemistry, Graduate School of Engineering, Kyoto University, Katsura, Nishikyo-ku, Kyoto 615-8510, Japan. \\ Correspondence should be addressed to S.S. (ssando@sbchem.kyoto-u.ac.jp) or Y.A. (aoyamay@sbchem.kyoto-u.ac.jp).
}

published online 3 May 2007; doi:10.1038/nprot.2007.140

\begin{abstract}
DNA sensing at a single nucleotide resolution is achieved using a hairpin-shaped, unmodified (unlabeled) RNA probe or the precursor double-stranded DNA (dsDNA) in a prokaryotic cell-free translation medium. The molecular-beacon-like probe consists of a loop region that is complementary to the target sequence and a stem composed of a ribosome-binding site (RBS) and its docking domain; the RBS is followed by the gene for a reporter protein such as luciferase or $\beta$-galactosidase. Target binding at the loop opens the hairpin to make RBS accessible by the ribosome to start translation of the reporter protein. This sensing system is signal amplifying by virtue of catalytic DNA-to-RNA transcription when using a dsDNA probe, catalytic RNA-to-protein translation, catalytic signal transduction by the enzymatic reaction of the translated reporter protein and, in the presence of RNase $\mathrm{H}$, catalytic or even irreversible translation-activation of the target-probe heteroduplex. Preparation of a probe takes 1-3 d and gene sensing using the probe takes 1-3 h.
\end{abstract}

\section{INTRODUCTION}

Coupling of molecular beacon strategy to cis-acting RNA-controlled protein translation

As the number of identified genes continues to grow, the need increases for rapid and simple gene sensing with high sequence selectivity ${ }^{1,2}$. Gene sensing of any type is based on selective targetprobe hybridization and its output, which should be easily monitored. Molecular beacons (MBs) with a fluorescence resonance energy transfer (FRET) pair (Fig. 1a) ${ }^{3}$ utilize hybridizationinduced conformational change of the probe from the light-off hairpin structure to a light-on open form. Much recent attention has also been paid to catalytic gene sensing ${ }^{4-13}$ through coupling to a signal-amplifying enzymatic ${ }^{4-8}$, chemical $^{9,10}$, electrochemical ${ }^{11}$ or magnetochemical ${ }^{12}$ process. On the other hand, we reported a new strategy with MB-mRNA systems for selective genotyping ${ }^{13}$. This is based on naturally occurring ${ }^{14}$ or engineered ${ }^{15}$ hairpinshaped or MB-like RNAs capable of riboregulator-dependent conformational change to control the translation activity, so that the sensing of the target oligodeoxynucleotide $(\mathrm{ODN})$ as a regulator can be performed using a genetically encodable unmodified RNA as a probe in a typical prokaryotic translation system.

\section{Design of MB-mRNA probes}

The artificial translation regulation system (MB-mRNA; Fig. 1b) is composed of a cis-acting MB-like RNA structure, wherein the loop region (blue) is complementary to the target (green) and the stem consists of sequences for a ribosome-binding site (RBS; red) and the anti-RBS or RBS-docking domain complementary thereto (pink) ${ }^{13}$. The RBS is followed by a reporter gene sequence starting with an AUG start codon. The anti-RBS domain is preceded by another hairpin structure ${ }^{16}$. This is to endow an anti-RNase stability. Binding of the target (green) at the loop is expected to result in the opening of the MB structure, making the RBS domain accessible by the ribosome and hence initiating the translation of the reporter gene, such as luciferase.
The balance of the loop and the stem in terms of base-pair (bp) length is critical for sensitivity and selectivity. If the stem is long, the hairpin structure will be more stabilized and will be opened only by a longer target capable of more extensive target-probe hybridization. This will give a high sensitivity-that is, high target-on/targetoff signal ratio-but low sequence selectivity. If, on the other hand,

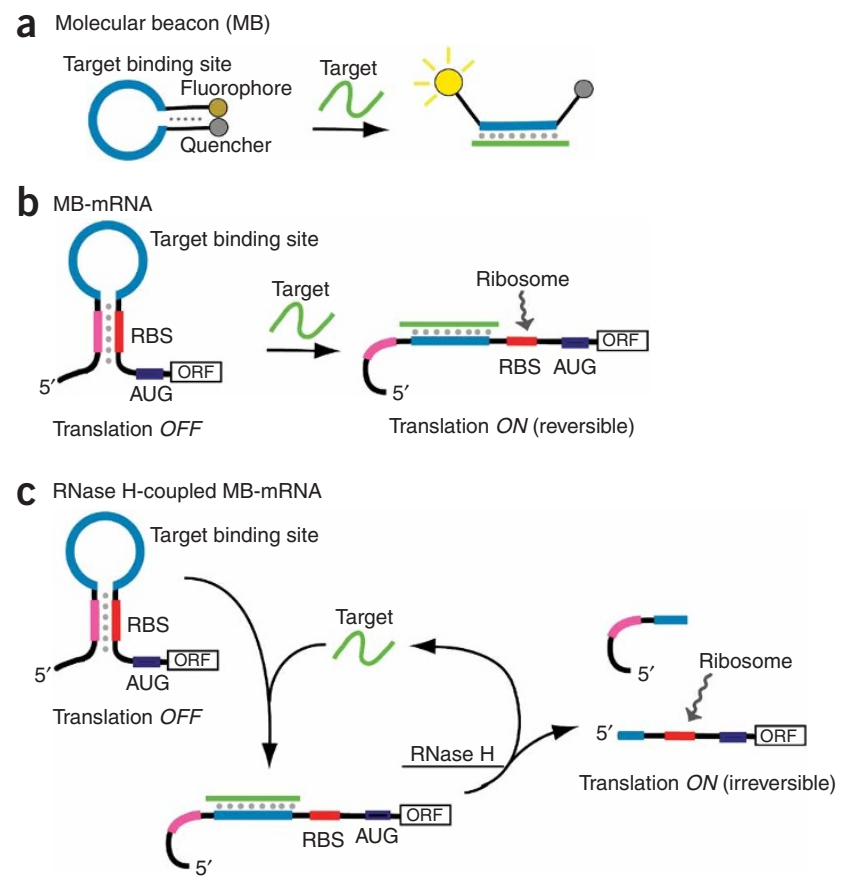

Figure 1 | Illustration of gene sensing systems. (a) MB, (b) MB-mRNA and (c) RNase $\mathrm{H}$-coupled MB-mRNA sensing systems. The ribosome-binding site (RBS), anti-RBS or RBS-docking site, start codon, target-binding domain and target are shown in red, pink, purple, blue and green, respectively. 


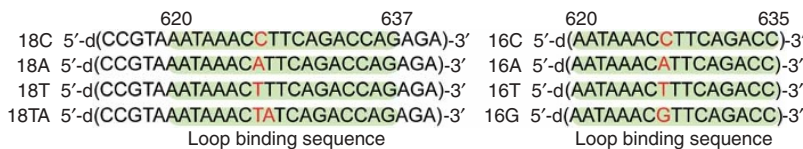

Loop binding sequence

Figure 2 | Oligodeoxynucleotide targets. An 18-nt or 16-nt loop binding sequence is shown in green.

the stem is short, the hairpin structure will be less stabilized and easily opened even by a shorter target. This will give high sequence selectivity but a low sensitivity. Actually, we chose the commonly encountered 6-base AGGAGA sequence as RBS and set, after trial and error, an 8-bp stem and 18- or 16-bp target-probe hybridization at the loop to optimize sensitivity and selectivity.

\section{Advantage of the method}

The construction of MB-mRNA probes is apparently complex. The actual sensing takes time because it includes many steps of enzymatic conversion. The sensitivity or detection limit, $9 \mathrm{fmol}$ (3.6 nM) as shown below, is not very high compared with those achieved recently by other methods ${ }^{17}$. Nevertheless, the present system has a number of unique aspects. (i) The unmodified (unlabeled) probe can be provided not only as RNA (MBmRNA) but also in the form of much more stable and directly PCR-amplifiable double-stranded DNA (dsDNA), as the former is transcribed in situ from the latter in the cell-free translation system. (ii) The essential transcription and translation are natural processes of the cells. (iii) The sensing is multiply catalytic or signal amplifying, as all of the respective steps - that is, transcription of DNA to RNA, translation of RNA to protein and transduction of signal (chemiluminescence, for example) from the enzymatic reaction of the translated reporter protein-are catalytic. These aspects suggest that the present system is potentially applicable to in-cell gene sensing, as there are established protocols for the cellular uptake of dsDNA and expression therein of the encoded gene into protein. PCR-based methods, on the other hand, cannot be used in cells. The applicability of artificial signal-amplifying systems in cells is highly questionable. The usefulness of labeled probes in cells also remains to be elucidated as regards to the efficacy of cellular uptake, extent of toxicity and compatibility of the sensing reaction, such as FRET, with cellular environments.

Another merit of the present system is that the reporter protein can, in principle, be of any type. This is particularly important in terms of single nucleotide polymorphism (SNP) detection, since we can easily construct a set of allele-sensitive probes using a class of otherwise closely related reporter proteins that can be distinguished from each other.

\section{Outline of protocol}

Although our ultimate goal is to establish in vivo gene sensing using the present system, the scope of this protocol is to describe its in vitro performance at a quantitative level, thus providing a basis for its in-cell application on one hand and, on the other hand, a guideline for the in vitro use of RNA systems for selection/sensing of translation-controlling small molecules (riboswitches) ${ }^{18}$. The targets are ODNs (Fig. 2) copying the 18-nt (620-637) or 16-nt (620-635) sequence (green) of the HIV 1-related human CC chemokine receptor 5 (CCR5) with a mutation at position 627 (ref. 19). The actual targets with variation at the corresponding
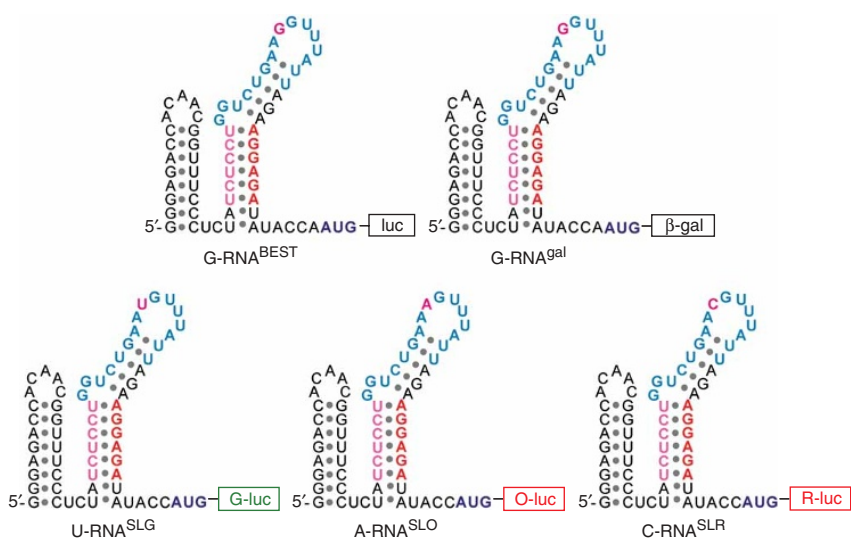

Figure 3 | Predicted secondary structures of the MB-mRNA probes. These contain the ORF domain for the reporter protein (either luciferase or $\beta$-galactosidase), RBS (red), target-binding site (blue) with 1-nt mutation shown in red and anti-RBS sequence (pink).

position shown in red are designated $18 \mathrm{X}$ and $16 \mathrm{X}(\mathrm{X}=\mathrm{A}, \mathrm{T}, \mathrm{C}$ or G) (Fig. 2). We also used a doubly mutated target 18TA.

Luciferase was our first choice as sensing output because of its high sensitivity, the good linearity of the related chemiluminescence assay and the ready color tuning (see below). Although this system requires luciferin as an external assay reagent, the latter is readily taken up into the cell and can thus be used for in vivo sensing ${ }^{20}$. A prototypical 18C-targeting MB-mRNA probe, designated G-RNA ${ }^{\mathrm{BEST}}$ (Fig. 3), was obtained by sequential PCRs on the luciferase gene $(l u c)$ encoded in plasmid vector pBESTluc and subsequent transcription (Fig. 4). The first PCR added the RBS (red), an 18-nt target-binding site (blue) with a targetcomplementary $\mathrm{G}$ base, and an intervening spacer. The second PCR added an anti-RBS domain (pink) and an additional hairpin structure preceded by the T7 promoter region. The primer sequences used are summarized in Figure 5. For sequence-selective production of multicolor reporter proteins, we took advantage

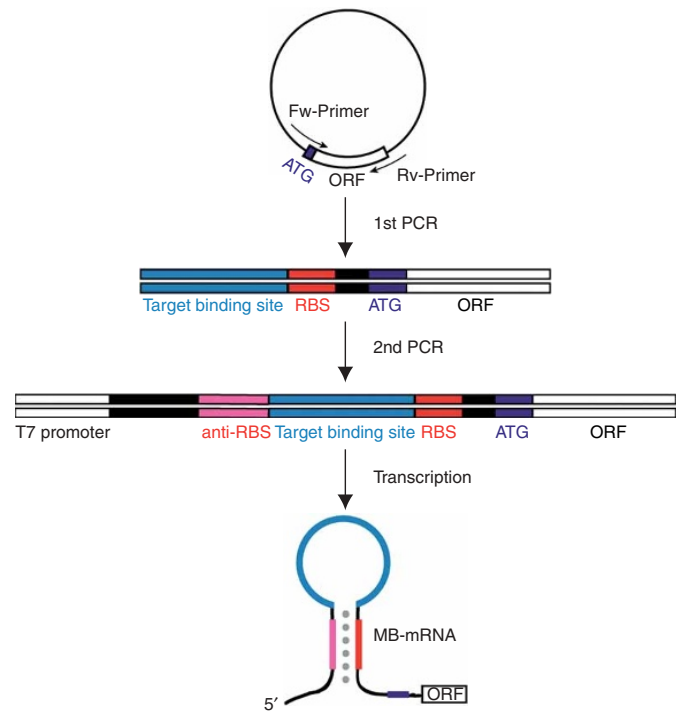

Figure 4 | Illustration of the preparation of MB-mRNA probes. This starts from a plasmid vector encoding a reporter protein. 
of the MultiReporter Assay System. Three plasmid vectors, pSLG-test, pSLO-test and pSLR-test, encode green-luminescing widetype Rhagophthalmus ohbai firefly luciferase (G-luc; emission maximum, $550 \mathrm{~nm}$ ), orange-luminescing mutated (T226N) R. ohbai firefly luciferase (O-luc; $580 \mathrm{~nm}$ ) and red-luminescing wild-type Phrixothrix hirtus firefly luciferase (R-luc; $630 \mathrm{~nm}$ ), respectively ${ }^{21-23}$. They were PCR-amplified as above to incorporate an A-sensitive, T-sensitive or G-sensitive target-binding site, respectively, to give U-RNA ${ }^{\text {SLG }}, A-R N A^{\text {SLO }}$ and C-RNA ${ }^{\text {SLR }}$ (Fig. 3). We also prepared an 18C-targeting probe, G-DNAgal (Fig. 3), encoding $\beta$-galactosidase $(\beta$-gal). The latter cleaves $o$ nitrophenyl $\beta$-galactoside as a substrate to give colored $o$-nitrophenol for colorimetric or visual assay.

To further enhance catalytic performance, we also use RNase $\mathrm{H}$. The translation-activated mRNA probe reversibly formed from stoichiometric binding of the target to the probe (structure on the right-hand side of Fig. 1b) is, at best, equimolar to the target. This would lead to low signal intensity, especially when the target is present in a tiny amount. RNase $\mathrm{H}$ is an endonuclease that specifically cleaves RNA in the DNA/RNA heteroduple ${ }^{24}$. It thus irreversibly digests the target-bound loop region of the probe to release the anti-RBS domain from the mRNA body, thus allowing

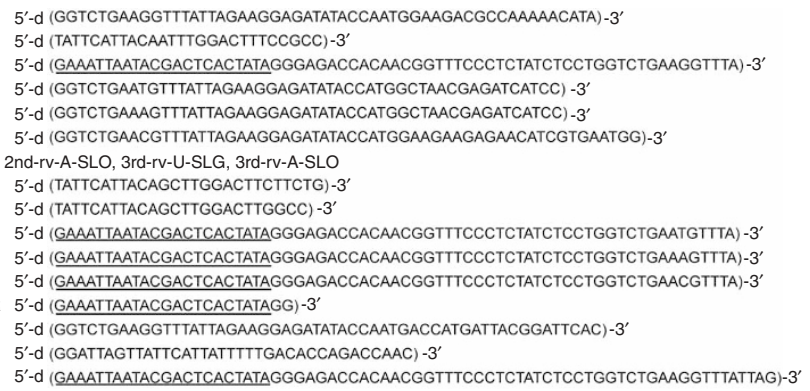

5 '-d (GAAATTAATACGACTCACTATAGGGAGACCACAACGGTTTCCCTCTATCTCCTGGTCTGAAGGTTTATTAG)-3'

\section{MATERIALS}

\section{REAGENTS}

- Agarose for 50-800-bp fragments (Nacalai Tesque, cat. no. 01147-96) for gel electrophoresis (see REAGENT SETUP)

- $\beta$-Galactosidase enzyme assay system (Promega, cat. no. E2000)

accompanied by the reporter lysis buffer

- DNA oligomers as primers in PCR (made to order by Gene Design Inc.)

- DNA stable marker 1-kbp ladder (Sigma Genosys, cat. no.

MBMA1KBP-S)

- DNeasy tissue kit (Qiagen, cat. no. 69504) for purification of total DNAs

- dNTPs (accompanied by respective polymerase samples)

-E. coli K-12 MG1655 strain (ATCC, for example)

-Ethidium bromide solution (Nippon Gene, cat. no. 315-90051) for gel electrophoresis ! CAUTION Toxic.

-Ethanol (Wako Pure Chemical Industries, cat. no. 053-06531) ! CAUTION

Highly flammable.

- GFX PCR DNA and gel band purification kit (GE Healthcare, cat. no.

27-9602-01) for purification of PCR products

- Luciferase assay kit (Promega, cat. no. E1501)

- Luria broth base powder (Invitrogen, cat. no. 12795-027)

- MEGAShortScript T7 (Ambion, cat. no. 1354) or MEGAScript T7 Kit

(Ambion, cat. no. 1333) for transcription

- pBESTluc vector (Promega)

-pSLG-test vector (Toyobo, cat. no. MRV-101)

- pSLO-test vector (Toyobo, cat. no. MRV-102)

- pSLR-test vector (Toyobo, cat. no. MRV-103)

- PfuUltra high-fidelity DNA polymerase (Stratagene, cat. no. 600380) for PCR

- Pure system standard classic II (Post Genome Institute, cat. no. PURE2030C) or pure system classic I (Post Genome Institute) as a reconstituted prokaryotic transcription/translation medium

- Pyrobest DNA polymerase (Takara, cat. no. R005A) for PCR

- RNase-free water (molecular biology reagent) (Sigma, cat. no. W4502)

$\triangle$ CRITICAL RNase-free water should be used throughout the procedure.

- RNeasy MinElute Cleanup kit (Qiagen, cat. no. 74204) for purification of RNA catalytic use of target DNA (RNase H-coupled MB-mRNA; Fig. 1c) with improved selectivity and enhanced sensitivity ${ }^{25}$, although, given the nature of RNase $\mathrm{H}$, it can be used only in vitro for DNA targets and not for in-cell gene sensing, where the targets should be mRNAs.

The translation- or transcription/translation-coupled sensing of ODN targets can be carried out in a normal Escherichia coli S30 extract system such as RTS HY100 (Roche), but we use a reconstituted prokaryotic cell-free transcription/translation system (Pure System; Post Genome Institute) ${ }^{26}$ throughout this work. Colorimetric assay of $\beta$-galactosidase cannot be conducted in the E. coli extract, which itself contains the enzyme. The effect of RNase $\mathrm{H}$ can also be most clearly evaluated in the reconstituted medium, which is otherwise free from RNase $\mathrm{H}$.
- TaKaRa Ex Taq hot start version (TaKaRa, cat. no. RR006A) for PCR

-Tris-Acetate-EDTA (TAE) buffer $(50 \times)$ (Nacalai Tesque, cat. no.

32666-81)

- Tth RNase H (Toyobo, cat. no. RNH-201)

- Buffer RPE (see REAGENT SETUP)

- LB medium (see REAGENT SETUP)

- Buffer AW1 (see REAGENT SETUP)

- Buffer AW2 (see REAGENT SETUP)

EQUIPMENT

- 96-well assay plate (Costar)

- Bio-shaker (Taitec, cat. no. BR-300LF)

- Centrifuge (Waken, model 2320)

- Densitograph (ATTO, cat. no. AE-6920V-FX)

- GeneQuant pro (GE Healthcare)

- iCycler thermalcycler dual block (Bio-Rad) for PCR

- Lumat LB9507 luminometer (Berthold Detection System)

- $i$-Mupid (COSMO BIO) for electrophoresis

- Multilabel counter (Wallac, cat. no. 1420) for luciferase/galactosidase assay

-25-ml reagent reservoir (VistaLab) for multichannel pipetting

- Surgical stainless steel blades and handles (Feather Safety Razor) for gel cutting

\section{REAGENT SETUP}

1\% Agarose gel Weigh $0.5 \mathrm{~g}$ agarose, and dissolve in $50 \mathrm{ml}$ MilliQ-grade deionized hot water. When the solution has cooled to $50{ }^{\circ} \mathrm{C}$, add $1 \mathrm{ml} 50 \times \mathrm{TAE}$ buffer and $5 \mu 10 \mu \mathrm{gl}^{-1}$ ethidium bromide solution. Mix thoroughly, and pour into gel tray.

Buffer RPE Combine $11 \mathrm{ml}$ of the supplied concentrated buffer RPE (RNeasy MinElute Cleanup kit) and $44 \mathrm{ml}$ ethanol.

Buffer AW1 Combine $19 \mathrm{ml}$ of the supplied concentrated buffer AW1 (DNeasy Tisssue kit) and $25 \mathrm{ml}$ ethanol.

Buffer AW2 Combine $13 \mathrm{ml}$ of the supplied concentrated buffer AW2 (DNeasy Tisssue kit) and $30 \mathrm{ml}$ ethanol.

LB medium Combine $7.5 \mathrm{~g}$ Luria broth base powder (Invitrogen) and $300 \mathrm{ml}$ MilliQ-grade deionized water, and heat the mixture in an autoclave at $121^{\circ} \mathrm{C}$ for $20 \mathrm{~min}$. 
PROTOCOL

\section{PROCEDURE}

Preparation of template dsDNA (G-DNA ${ }^{\mathrm{BEST}}$ ) $\odot$ TIMING $\mathbf{5} \mathbf{h}$

1) Prepare a first PCR mix containing the following:

\begin{tabular}{lc}
\hline Reagents & Volume $(\boldsymbol{\mu l})$ \\
\hline $10 \times$ PfuUltra reaction buffer & 2.5 \\
dNTPs (2 mM each) & 2.5 \\
Forward primer (1st-fw-G-BEST; Fig. 5) $(2 \mu \mathrm{M})$ & 2.5 \\
Reverse primer (1st-rv-G-BEST; Fig. 5) $(2 \mu \mathrm{M})$ & 2.5 \\
PfuUltra DNA polymerase $\left(2.5 \mathrm{U}^{-1}\right)$ & 0.5 \\
$\mathrm{H}_{2} \mathrm{O}$ & 13.5 \\
Total volume & 24 \\
\hline
\end{tabular}

$\Delta$ CRITICAL STEP To prevent contamination, use nuclease-free filter tips.

2| Add $1 \mu \mathrm{l} \mathrm{pBESTluc} \mathrm{solution} \mathrm{(} 5 \mathrm{ng} \mu^{-1}$ ) or $1 \mu \mathrm{l}$ water (for negative control) to each mix in a PCR tube.

3| Run the following PCR cycles:

\begin{tabular}{|c|c|c|c|c|}
\hline Cycle number & Denaturation & Annealing & Polymerization & Final \\
\hline \multicolumn{5}{|l|}{$3 \mathrm{~min}$ at $95^{\circ} \mathrm{C}$} \\
\hline $2-31$ & $45 \mathrm{~s}$ at $95^{\circ} \mathrm{C}$ & $45 \mathrm{~s}$ at $54^{\circ} \mathrm{C}$ & 1 min at $72^{\circ} \mathrm{C}$ & \\
\hline 32 & & & 10 min at $72{ }^{\circ} \mathrm{C}$ & \\
\hline Hold & & & & $4^{\circ} \mathrm{C}$ \\
\hline
\end{tabular}

4 Check the PCR by running $5 \mu$ l of each reaction mixture on a $1 \%$ agarose gel with a $1-\mathrm{kbp}$ ladder as a marker.

PAUSE POINT The PCR product can be stored at $-80{ }^{\circ} \mathrm{C}$ for 3 months.

5| Dilute the PCR product with water to give a 1:99 dilution.

6| Prepare a second PCR mix containing the following:

\begin{tabular}{lc}
\hline Reagents & Volume $(\boldsymbol{\mu l})$ \\
\hline $10 \times$ PfuUltra reaction buffer & 2.5 \\
dNTPs (2 mM each) & 2.5 \\
Forward primer (2nd-fw-G-BEST; Fig. 5) $(2 \mu \mathrm{M})$ & 2.5 \\
Reverse primer (2nd-rv-G-BEST; Fig. 5) $(2 \mu \mathrm{M})$ & 2.5 \\
PfuUltra DNA polymerase $\left(2.5 U \mu \mathrm{l}^{-1}\right)$ & 0.5 \\
$\mathrm{H}_{2} \mathrm{O}$ & 13.5 \\
Total volume & 24 \\
\hline
\end{tabular}

$\triangle$ CRITICAL STEP To prevent contamination, use nuclease-free filter tips.

7| Add $1 \mu \mathrm{l}$ of the diluted first PCR solution or $1 \mu \mathrm{l}$ water (for negative control) to each mix in a PCR tube.

8| Perform the PCR in the same manner as in Step 3, and check as in Step 4 to ensure the formation of the desired, allele C-targeting dsDNA template (G-DNA ${ }^{\text {BEST }}$ ).

$\triangle$ CRITICAL STEP If the purity (as judged by gel electrophoresis) is not satisfactory (more than one spot), purify the PCR product with a GFX PCR DNA and gel band purification kit for subsequent transcription to give a single spot.

- PAUSE POINT The PCR product can be stored at $-80^{\circ} \mathrm{C}$ for 3 months.

\section{Preparation of RNA probe G-RNA ${ }^{\text {BEST }}$ TIMING $15 \mathrm{~h}$}

9| Prepare the following MEGAshortscript T7 transcription mix in a PCR tube (MEGAscript T7 can be used in place of MEGAshortscript):

\begin{tabular}{lc}
\hline Reagents & Volume $(\boldsymbol{\mu l})$ \\
\hline T7 10× reaction buffer & 2.0 \\
T7 NTP solution (75 mM) & 2.0 each \\
T7 enzyme mix & 2.0 \\
G-DNA & 2.0 \\
$\mathrm{H}_{2} \mathrm{O}$ & 6.0 \\
Total volume & 6.0 \\
\hline
\end{tabular}


10| Mix briefly, spin down and tap the sample.

PAUSE POINT Incubate the mixture overnight at $37^{\circ} \mathrm{C}$.

11| To decompose the DNA template, add $1 \mu$ TURBO DNase solution, mix well and incubate at $37^{\circ} \mathrm{C}$ for $15 \mathrm{~min}$.

12| Purify the transcribed RNA probe (G-RNA ${ }^{\mathrm{BEST}}$ ) with an RNeasy MinElute Cleanup Kit according to the manufacturer's manual.

13| Determine the concentration of the purified probe by the absorbance at $260 \mathrm{~nm}$, and dilute to give a stock solution of G-RNA ${ }^{\text {BEST }}\left(1 \mu \mathrm{g} \mathrm{l}^{-1}\right)$.

$\triangle$ CRITICAL STEP Avoid repeated freezing and thawing of the sample, because this results in decomposition of the RNA. For repeated use, divide the stock solution into $10-\mu \mathrm{l}$ aliquots and freeze separately.

PAUSE POINT The transcription product (G-RNA ${ }^{\mathrm{BEST}}$ ) can be stored at $-80{ }^{\circ} \mathrm{C}$ for 2 weeks.

RNase $\mathrm{H}$-uncoupled sensing of 18-nt targets with probe G-RNA ${ }^{\text {BEST }} \bigcirc$ TIMING $1.5 \mathrm{~h}$

14| Prepare a reconstituted prokaryotic translation medium (solution $A B$ ) by mixing $35 \mu \mathrm{l}$ of solution $A$ and $5 \mu$ l of solution $B$ of pure system classic $I$.

$\triangle$ CRITICAL STEP A normal E. coli S30 extract system (RTS HY100, Roche, cat no. 3186 148) can be used with similar results in place of the reconstituted translation system.

15 Mix probe G-RNA ${ }^{\text {BEST }}$ and 18-nt full-match target (18C) in a PCR tube, as follows:

\begin{tabular}{lc}
\hline Reagents & Volume $(\mu \mathrm{l})$ \\
\hline Solution $\mathrm{AB}$ & 8.0 \\
Probe G-RNA & 1.0 \\
Target $18 \mathrm{C}\left(1.8 \mathrm{pmol}^{\mathrm{B}} \mathrm{L}^{-1}\right)$ & 1.0 \\
Total volume & 10 \\
\hline
\end{tabular}

For negative control, add $1 \mu \mathrm{l}$ water in place of target $18 \mathrm{C}$.

$\triangle$ CRITICAL STEP Negative control without target is critical, as the target-on chemiluminescence intensity should always be evaluated in reference to that in the absence of the target.

16| Spin down and tap the mixture gently, and incubate for $1 \mathrm{~h}$ at $37^{\circ} \mathrm{C}$.

17| Add $10 \mu$ water into each sample in the tube.

18| Take three 5 - $\mu$ l aliquots from each sample, and put them separately in a 96 -well assay plate set in a multilabel counter (Wallac 1420).

19| Add $100 \mu$ luciferase assay reagent to each well, and read the chemiluminescence intensity $(I)$. Confirm that the presence of the probe gives rise to approximately threefold higher intensity than is seen in its absence $\left(I_{\text {on }} / I_{\text {off }} \cong 3\right)$.

$\triangle$ CRITICAL STEP To standardize conditions for all samples, it is critical to use a multichannel pipette and reagent reservoir and to read the chemiluminescence intensity immediately after mixing the sample with the reagent by pipetting. Chemiluminescence intensity gradually decreases in a time-dependent manner, giving approximately $50 \%$ loss of intensity in 10 min.

? TROUBLESHOOTING

RNase $\mathbf{H}$-coupled sensing of 18-nt and 16-nt targets with probe G-RNA ${ }^{\text {BEST }} \bigcirc$ TIMING $2 \mathbf{h}$ for each set of targets

20| For RNase H-coupled sensing, mix probe G-RNA ${ }^{\mathrm{BEST}}$, 18-nt target (fully matched 18C, singly A-mismatched 18A, singly

T-mismatched $18 \mathrm{~T}$ or doubly TA-mismatched $18 \mathrm{TA}$ ) and RNase $\mathrm{H}$ in a PCR tube, as follows:

\begin{tabular}{|c|c|}
\hline Reagents & Volume $(\mu \mathrm{l})$ \\
\hline Solution AB & 8.0 \\
\hline Probe G-RNA ${ }^{\text {BEST }}$ (Step 13) $\left(1 \mu \mathrm{g} \mu \mathrm{l}^{-1}\right.$ or $\left.1.8 \mathrm{pmol} \mu \mathrm{l}^{-1}\right)$ & 1.0 \\
\hline Target $18 \mathrm{C}, 18 \mathrm{~A}$ or $18 \mathrm{TA}\left(1.8 \mathrm{pmol} \mu \mathrm{l}^{-1}\right)$ & 1.0 \\
\hline Tth RNase $\mathrm{H}\left(0.1 \cup \mu \mathrm{l}^{-1}\right)$ & 1.0 \\
\hline Total volume & 11 \\
\hline
\end{tabular}

For negative control, add $1 \mu \mathrm{l}$ water in place of target ODN.

$\triangle$ CRITICAL STEP Negative control without target is essential, as the target-on chemiluminescence intensity should always be evaluated in reference to that in the absence of the target.

21| Follow the translation (Step 16), workup (Steps 17 and 18) and assay (Step 19) procedures as above with $9 \mu \mathrm{l}$ water in place of $10 \mu \mathrm{l}$ in Step 17. Confirm that the $I_{\text {on }} / I_{\text {off }}$ ratio (target-on to target-off signal ratio) for the full-match target $18 \mathrm{C}$ is enhanced from 3 (in the absence of RNase $\mathrm{H}$ ) to 6 (in its presence) with more (for 18A and 18TA) or less (for 18T) efficient base discrimination. 
PROTOCOL

$\triangle$ CRITICAL STEP To standardize conditions for all samples, it is critical to use a multichannel pipette and reagent reservoir and to read the chemiluminescence intensity immediately after mixing the sample with the reagent by pipetting. Chemiluminescence intensity gradually decreases in a time-dependent manner, giving approximately $50 \%$ loss of intensity in 10 min.

$\triangle$ CRITICAL STEP To see the clear effect of RNase $\mathrm{H}$, it is critical to use the reconstituted translation system, which is free from RNase $\mathrm{H}$.

\section{? TROUBLESHOOTING}

22 To check the effect of base-pair length in target-probe hybridization, use 16-nt targets (fully matched 16C and singly T-mismatched 16T) in place of the 18-nt counterparts under RNase H-uncoupled (Steps 15-19) and RNase H-coupled (Steps 20 and 21) conditions. Confirm that a significant on/off ratio $\left(I_{\mathrm{on}} / I_{\text {off }} \cong 6\right)$ is achieved only for the full-match target $16 \mathrm{C}$, with a satisfactory T-allele discrimination capacity, under the RNase $\mathrm{H}$-coupled conditions.

$\triangle$ CRITICAL STEP To standardize conditions for all samples, it is critical to use a multichannel pipette and reagent reservoir and to read the chemiluminescence intensity immediately after mixing the sample with the reagent by pipetting. Chemiluminescence intensity gradually decreases in a time-dependent manner, giving approximately $50 \%$ loss of intensity in $10 \mathrm{~min}$.

\section{? TROUBLESHOOTING}

\section{RNase $\mathrm{H}$-coupled sensing with G-DNA ${ }^{\mathrm{BEST}}$ as a probe TIMING $1.5 \mathrm{~h}$}

23| Mix dsDNA template G-DNA ${ }^{\text {BEST }}$ (Step 8), 18-nt full-match target $18 \mathrm{C}$ and RNase $\mathrm{H}$ in a PCR tube, as follows:

\begin{tabular}{|c|c|}
\hline Reagents & Volume $(\mu \mathrm{l})$ \\
\hline Solution AB & 8.0 \\
\hline Probe G-DNA ${ }^{\text {BEST }}$ (Step 8) $\left(0.2 \mathrm{pmol}_{\mu \mathrm{l}^{-1}}\right)$ & 1.0 \\
\hline Target $18 \mathrm{C}\left(1.8 \mathrm{pmol} \mu \mathrm{l}^{-1}\right)$ & 1.0 \\
\hline Tth RNase $\mathrm{H}\left(0.1 \mathrm{U} \mu \mathrm{l}^{-1}\right)$ & 1.0 \\
\hline Total volume & 11 \\
\hline
\end{tabular}

For negative control, add $1 \mu \mathrm{l}$ water in place of target $18 \mathrm{C}$.

$\triangle$ CRITICAL STEP Negative control without target is essential, as the target-on chemiluminescence intensity should always be evaluated in reference to that in the absence of the target.

24| Follow the translation (Step 16), workup (Steps 17 and 18) and assay (Step 19) procedures as above with $9 \mu \mathrm{l}$ water in place of $10 \mu \mathrm{l}$ in Step 17. Confirm that the on/off ratio is much enhanced, to approximately 13.

$\triangle$ CRITICAL STEP To standardize conditions for all samples, it is critical to use a multichannel pipette and reagent reservoir and to read the chemiluminescence intensity immediately after mixing the sample with the reagent by pipetting. Chemiluminescence intensity gradually decreases in a time-dependent manner, giving approximately $50 \%$ loss of intensity in 10 min.

? TROUBLESHOOTING

Preparation of template dsDNAs of multicolor reporter proteins (T-DNA ${ }^{\text {SLG }}$, A-DNA ${ }^{\text {SL0 }}$ and C-DNA ${ }^{\text {SLR }}$ ) $\odot$ TIMING $6 \mathrm{~h}$ for each template

25| For the preparation of T-DNA ${ }^{\mathrm{SLG}}$, which is transcribable into A-targeting U-RNA ${ }^{\mathrm{SLG}}$, prepare a first PCR mix containing the following:

\begin{tabular}{lc}
\hline Reagents & Volume $(\boldsymbol{\mu l})$ \\
\hline $10 \times$ Pyrobest buffer II & 2.0 \\
dNTPs (2.5 mM each) & 2.0 \\
Forward primer (1st-fw-U-SLG; Fig. 5) $(2 \mu \mathrm{M})$ & 2.0 \\
Reverse primer (1st-rv-U-SLG; Fig. 5) $(2 \mu \mathrm{M})$ & 2.0 \\
Pyrobest DNA polymerase (1.0 U $\left.\mu \mathrm{l}^{-1}\right)$ & 1.25 \\
$\mathrm{H}_{2} \mathrm{O}$ & 8.75 \\
Total volume & 18 \\
\hline
\end{tabular}

$\triangle$ CRITICAL STEP To prevent contamination, use nuclease-free filter tips.

26| Add $2 \mu$ l solution of green luciferase-encoding vector pSLG-test $\left(5 \mathrm{ng} \mu \mathrm{l}^{-1}\right)$ or $2 \mu \mathrm{l}$ water (for negative control) to each mix in a PCR tube.

27| Run the following PCR cycles:

\begin{tabular}{lllll}
\hline Cycle number & Denaturation & Annealing & Polymerization & Final \\
\hline $\begin{array}{l}1-20 \\
\text { Hold }\end{array}$ & $10 \mathrm{~s}$ at $98{ }^{\circ} \mathrm{C}$ & $30 \mathrm{~s}$ at $56^{\circ} \mathrm{C}$ & 1 min at $72{ }^{\circ} \mathrm{C}$ & \\
\hline
\end{tabular}


28| Check the PCR by running $5 \mu \mathrm{l}$ of reaction mixture on a $1 \%$ agarose gel with a 1-kbp ladder as a marker. If the purity (as judged by gel electrophoresis) is not satisfactory (more than one spot), purify the PCR product with a GFX PCR DNA and gel band purification kit according to the manufacturer's manual.

PAUSE POINT The PCR product can be stored at $-80^{\circ} \mathrm{C}$ for 3 months.

29| Dilute the purified PCR product with water to give a 1:199 dilution.

30| Prepare a second PCR mix containing the following:

\begin{tabular}{lc}
\hline Reagents & Volume $(\boldsymbol{\mu l})$ \\
\hline $10 \times$ Pyrobest buffer II & 2.0 \\
dNTPs (2.5 mM each) & 2.0 \\
Forward primer (2nd-fw-U-SLG; Fig. 5) $(2 \mu \mathrm{M})$ & 2.0 \\
Reverse primer (2nd-rv-U-SLG; Fig. 5) $(2 \mu \mathrm{M})$ & 2.0 \\
Pyrobest DNA polymerase $\left(1.0 \cup \mu \mathrm{l}^{-1}\right)$ & 1.25 \\
$\mathrm{H}_{2} \mathrm{O}$ & 9.75 \\
Total volume & 19 \\
\hline
\end{tabular}

CRITICAL STEP To prevent contamination, use nuclease-free filter tips.

31 Add $1 \mu \mathrm{l}$ of the diluted purified first PCR solution or $1 \mu \mathrm{l}$ water (for negative control) to each mix in a PCR tube.

32| Perform the PCR in exactly the same manner as in Step 27.

33| Check the purity and, when it is not satisfactory, purify the product as in Step 28.

PAUSE POINT The PCR product can be stored at $-80^{\circ} \mathrm{C}$ for 3 months.

34| Dilute the purified second PCR product as in Step 29.

35| Prepare a third PCR mix containing the following:

\begin{tabular}{lc}
\hline Reagents & Volume $(\boldsymbol{\mu l})$ \\
\hline $10 \times$ Pyrobest buffer II & 2.0 \\
dNTPs (2.5 mM each) & 2.0 \\
Forward primer (3rd-fw-U-SLG; Fig. 5) $(2 \mu \mathrm{M})$ & 2.0 \\
Reverse primer (3rd-rv-U-SLG; Fig. 5) $(2 \mu \mathrm{M})$ & 2.0 \\
Pyrobest DNA polymerase $\left(1.0 \mathrm{UL}^{-1}\right)$ & 1.25 \\
$\mathrm{H}_{2} \mathrm{O}$ & 8.75 \\
Total volume & 18 \\
\hline
\end{tabular}

36| Add $2 \mu \mathrm{l}$ of the diluted purified second PCR solution or $2 \mu \mathrm{l}$ water (for negative control) to each mix in a PCR tube.

37| Perform the PCR in exactly the same manner as in Step 27.

38| Check the purity, and purify the product dsDNA, that is, T-DNA ${ }^{S L G}$, as in Step 28.

PAUSE POINT The PCR product can be stored at $-80^{\circ} \mathrm{C}$ for 3 months.

39| For the preparation of $\mathrm{A}-\mathrm{DNA} \mathrm{A}^{\mathrm{SL0}}$ transcribable into T-targeting A-RNA ${ }^{\mathrm{SLO}}$, follow Steps $25-38$ using orange luciferaseencoding vector pSL0-test and A-SL0 relevant primers (1st-fw-A-SL0, 1st-rv-A-SLO, 2nd-fw-A-SLO, 2nd-rv-A-SL0, 3rd-fw-A-SL0 and 3rd-rv-A-SLO) in place of pSLG-test (Step 26) and T-SLG relevant ones (1st-fw-U-SLG, 1st-rv-U-SLG, 2nd-fw-U-SLG and 2nd-rv-U-SLG, 3rd-fw-U-SLG and 3rd-rv-U-SLG) (Steps 25, 30 and 35).

40| For the preparation of C-DNA ${ }^{S L R}$ transcribable into G-targeting C-RNA ${ }^{S L R}$, follow Steps 25-38 using red luciferase-encoding vector pSLR-test and C-SLR relevant primers (1st-fw-C-SLR, 1st-rv-C-SLR, 2nd-fw-C-SLR, 2nd-rv-C-SLR, 3rd-fw-C-SLR and 3rd-rv-C-SLR) in place of pSLG-test (Step 26) and U-SLG relevant ones (1st-fw-U-SLG, 1st-rv-U-SLG, 2nd-fw-U-SLG, 2nd-rv-U-SLG, 3rd-fw-U-SLG and 3rd-rv-U-SLG) (Steps 25, 30 and 35).

Preparation of RNA probes, U-RNA ${ }^{\text {SLG }}$, A-RNA ${ }^{\text {SLO }}$ and C-RNA ${ }^{\text {SLR }} \bigcirc$ TIMING $15 \mathrm{~h}$ for each probe 41| For U-RNA $A^{S L G}$, prepare the following MEGAshortscript T7 transcription mix in a PCR tube (MEGAscript T7 can be used in place of MEGAshortscript): 
PROTOCOL

\begin{tabular}{lc}
\hline Reagents & Volume $(\boldsymbol{\mu l})$ \\
\hline T7 $10 \times$ reaction buffer & 1.0 \\
T7 NTP solution (75 mM) & 1.0 each \\
T7 enzyme mix & 1.0 \\
T-DNA & 3.0 \\
$\mathrm{H}_{2} \mathrm{O}$ & 1.0 \\
Total volume & 10 \\
\hline
\end{tabular}

42 Carry out transcription as in Steps 10-12. Determine the concentration of purified product by the absorbance at $260 \mathrm{~nm}$, and dilute to give a stock solution of probe U-RNA ${ }^{\text {SLG }}\left(1 \mu \mathrm{g} \mu \mathrm{l}^{-1}\right)$.

$\triangle$ CRITICAL STEP Avoid repeated freezing and thawing of the sample, because this results in decomposition of the RNA. For repeated use, divide the stock solution into $10-\mu \mathrm{l}$ aliquots and freeze.

PAUSE POINT The transcription product (U-RNA ${ }^{\mathrm{SLG}}$ ) can be stored at $-80^{\circ} \mathrm{C}$ for 2 weeks.

43| For the preparation of A-RNA ${ }^{\text {SLO }}$, follow Steps 41 and 42 using A-DNA ${ }^{S L 0}$ in place of T-DNA ${ }^{\text {SLG }}$.

44| For the preparation of C-RNA $A^{\text {SLR }}$, follow Steps 41 and 42 using C-DNA $A^{\text {SLR }}$ in place of T-DNA ${ }^{\text {SLG }}$.

\section{Sensing of 16-nt targets with allele-selective RNA probes TIMING 2 h for each set of targets}

45| Prepare a reconstituted prokaryotic translation medium (solution $A B$ ) by mixing $25 \mu$ l solution $A$ and $10 \mu$ solution $B$ of pure system classic II.

46| Mix probe U-RNA ${ }^{\text {SLG }}$, target $(16 \mathrm{~A}, 16 \mathrm{~T}, 16 \mathrm{C}$ or $16 \mathrm{G})$ and RNase $\mathrm{H}$ in a PCR tube, as follows:

\begin{tabular}{|c|c|}
\hline Reagents & Volume $(\mu \mathrm{l})$ \\
\hline Solution $A B$ & 8.0 \\
\hline Probe U-RNA ${ }^{\mathrm{SLG}}$ (Step 42) $\left(1 \mu \mathrm{g} \mu \mathrm{l}^{-1}\right.$ or $\left.1.8 \mathrm{pmol} \mu \mathrm{l}^{-1}\right)$ & 1.0 \\
\hline Target $16 \mathrm{~A}, 16 \mathrm{~T}, 16 \mathrm{C}$ or $16 \mathrm{G}\left(1.8 \mathrm{pmol} \mu \mathrm{l}^{-1}\right)$ & 1.0 \\
\hline Tth RNase $\mathrm{H}\left(1.0 \cup \mu \mathrm{l}^{-1}\right)$ & 1.0 \\
\hline Total volume & 11 \\
\hline
\end{tabular}

For negative control, add $1 \mu \mathrm{l}$ water in place of target ODN.

$\triangle$ CRITICAL STEP Negative control without target is essential, as the target-on chemiluminescence intensity should always be evaluated in reference to that in the absence of the target.

47| Carry out target-dependent translation of green luciferase as in Step 16. Follow the workup and assay procedures as in Steps $17-19$, but by adding $11 \mu \mathrm{l}$ water in place of $10 \mu \mathrm{l}$ in Step 17, taking $5.5-\mu \mathrm{l}$ aliquots in place of $5-\mu \mathrm{l}$ aliquots in Step 18 and using a luminometer in place of a multilabel counter. Confirm that only A-allele target $16 \mathrm{~A}$ gives rise to a significant increase in the chemiluminescence intensity, that is, on/off ratio.

$\triangle$ CRITICAL STEP To standardize conditions for all samples, it is critical to read the chemiluminescence intensity immediately after mixing the sample with the reagent by pipetting. Chemiluminescence intensity gradually decreases in a time-dependent manner, giving approximately $50 \%$ loss of intensity in $10 \mathrm{~min}$.

? TROUBLESHOOTING

48 Mix probe A-RNA ${ }^{\mathrm{SL} 0}$, target $(16 \mathrm{~A}, 16 \mathrm{~T}, 16 \mathrm{C}$ or $16 \mathrm{G})$ and RNase $\mathrm{H}$ in a PCR tube as in Step 46. Follow the translation and assay procedures in Step 47 for orange luciferase. Confirm that only T-allele target $16 \mathrm{~T}$ gives rise to a significant increase in the chemiluminescence intensity, that is, on/off ratio.

49| Mix probe C-RNA ${ }^{\mathrm{SLR}}$, target $(16 \mathrm{~A}, 16 \mathrm{~T}, 16 \mathrm{C}$ or $16 \mathrm{G})$ and RNase $\mathrm{H}$ in a PCR tube as in Step 46. Follow the translation and assay procedures in Step 47 for red luciferase. Confirm that only $\mathrm{G}$-allele target $16 \mathrm{G}$ gives rise to a significant increase in the chemiluminescence intensity, that is, on/off ratio.

$\triangle$ CRITICAL STEP For multicolor SNP detection in a single tube, it is critical to optimize the quantities of the three probes or use $I_{\mathrm{on}} / I_{\text {off }}$ criteria for evaluation, as the translation efficiencies and emission coefficients for the three types (green, orange and red) of luminescence are different.

Preparation of dsDNA template G-DNA ${ }^{\text {gal }}$ for a colorimetric assay based on a $\boldsymbol{\beta}$-galactosidase reporter protein $\bigcirc$ TIMING $25 \mathbf{h}$ 50| Inoculate $E$. coli $\mathrm{K}-12$ MG1655 strain in $5 \mathrm{ml}$ LB medium in a plastic tube.

51| Incubate the mixture for $16 \mathrm{~h}$ at $37^{\circ} \mathrm{C}$ with vigorous shaking. 
52| Purify total DNAs in the strain with a DNeasy tissue kit according to the manufacturer's manual.

53| Determine the concentration of the purified total DNAs by the absorbance at $260 \mathrm{~nm}$.

- PAUSE POINT The DNAs can be stored at $-80{ }^{\circ} \mathrm{C}$ for 3 months.

54| Prepare the first PCR mix containing the following:

\begin{tabular}{lc}
\hline Reagents & Volume $(\boldsymbol{\mu l})$ \\
\hline $10 \times$ Ex Taq buffer & 2.5 \\
dNTPs (2.5 mM each) & 2.0 \\
Forward primer (1st-fw-G-gal; Fig. 5) $(2 \mu \mathrm{M})$ & 2.5 \\
Reverse primer (1st-rv-G-gal; Fig. 5) $(2 \mu \mathrm{M})$ & 2.5 \\
Ex Taq DNA polymerase $\left(0.5 \mathrm{Ul}^{-1}\right)$ & 1.25 \\
$\mathrm{H}_{2} \mathrm{O}$ & 13.25 \\
Total volume & 24 \\
\hline
\end{tabular}

$\triangle$ CRITICAL STEP To prevent contamination, use nuclease-free filter tips.

55| Add $1 \mu$ l of the total DNA solution obtained above $\left(5 \mathrm{ng}^{-1}\right.$ ) or $1 \mu \mathrm{l}$ water (for negative control) to each mix in a PCR tube.

56| Run the following PCR cycles:

\begin{tabular}{|c|c|c|c|c|}
\hline Cycle number & Denaturation & Annealing & Polymerization & Final \\
\hline 1 & $2 \min$ at $94^{\circ} \mathrm{C}$ & & & \\
\hline $2-24$ & $15 \mathrm{~s}$ at $94^{\circ} \mathrm{C}$ & $15 \mathrm{~s}$ at $54^{\circ} \mathrm{C}$ & 2 min at $72{ }^{\circ} \mathrm{C}$ & \\
\hline 25 & & & $5 \min$ at $72{ }^{\circ} \mathrm{C}$ & \\
\hline Hold & & & & $4^{\circ} \mathrm{C}$ \\
\hline
\end{tabular}

57| Check the PCR by running $5 \mu$ l of each reaction on a $1 \%$ agarose gel with a $1-k b p$ ladder as a marker.

- PAUSE POINT The PCR product can be stored at $-80{ }^{\circ} \mathrm{C}$ for 3 months.

58| Dilute the PCR product with water to give a 1:99 dilution.

59| Prepare the second PCR mix containing the following:

\begin{tabular}{lc}
\hline Reagents & Volume $(\boldsymbol{\mu l})$ \\
\hline $10 \times$ Ex Taq buffer & 2.5 \\
dNTPs (2.5 mM each) & 2.0 \\
Forward primer (2nd-fw-G-gal; Fig. 5) $(2 \mu \mathrm{M})$ & 2.5 \\
Reverse primer (2nd-rv-G-gal; Fig. 5) $(2 \mu \mathrm{M})$ & 2.5 \\
Ex Taq DNA polymerase $\left(0.5 \mathrm{U}^{-1}\right)$ & 1.25 \\
$\mathrm{H}_{2} \mathrm{O}$ & 13.25 \\
Total volume & 24 \\
\hline
\end{tabular}

$\triangle$ CRITICAL STEP To prevent contamination, use nuclease-free filter tips.

60| Add $1 \mu \mathrm{l}$ of the diluted first PCR solution or $1 \mu \mathrm{l}$ water (for negative control) to each mix in a PCR tube.

61| Run the following PCR cycles:

\begin{tabular}{lllll}
\hline Cycle number & Denaturation & Annealing & Polymerization & Final \\
\hline 1 & $2 \min$ at $94^{\circ} \mathrm{C}$ & & & \\
$2-20$ & $15 \mathrm{~s}$ at $94^{\circ} \mathrm{C}$ & $15 \mathrm{~s}$ at $55{ }^{\circ} \mathrm{C}$ & $2 \min$ at $72{ }^{\circ} \mathrm{C}$ & \\
21 & & $5 \min$ at $72{ }^{\circ} \mathrm{C}$ & \\
Hold & & & $4{ }^{\circ} \mathrm{C}$ \\
\hline
\end{tabular}

62 Check as in Step 57 to make sure of the formation of the desired dsDNA template, that is, G-DNA ${ }^{\text {gal }}$.

PAUSE POINT The PCR product can be stored at $-80{ }^{\circ} \mathrm{C}$ for 3 months.

RNase $\mathbf{H}$-coupled sensing with G-DNA ${ }^{\text {gal }}$ as a probe $\bigcirc I M I N G \mathbf{2 . 5} \mathbf{h}$

63| Mix full-match 18-nt target $18 \mathrm{C}$, dsDNA probe G-DNA ${ }^{\text {gal }}$ and RNase $\mathrm{H}$ in a PCR tube, as follows: 
PROTOCOL

\begin{tabular}{lc}
\hline Reagents & Volume $(\mu \mathrm{l})$ \\
\hline Solution $\mathrm{AB}$ & 8.0 \\
Probe G-DNA & 1.0 \\
$\quad\left(0.2 \mathrm{pmol} \mu \mathrm{l}^{-1}\right)$ & \\
Target $18 \mathrm{C}\left(1.8 \mathrm{pmol}^{-1} \mathrm{l}^{-1}\right)$ & 1.0 \\
Tth RNase $\mathrm{H}\left(1 \mathrm{U} \mathrm{l}^{-1}\right)$ & 1.0 \\
Total volume & 11 \\
\hline
\end{tabular}

For negative control, add $1 \mu \mathrm{l}$ water in place of target $18 \mathrm{C}$.

$\triangle$ CRITICAL STEP Negative control without target is essential, as the targeton chemiluminescence intensity should always be evaluated in reference to that in the absence of the target.

$\triangle$ CRITICAL STEP It is critical to use the reconstituted translation system. A normal $E$. coli extract cannot be used, because it contains $\beta$-galactosidase.

64| Spin down and tap the mixture gently, and incubate for $1 \mathrm{~h}$ at $37^{\circ} \mathrm{C}$.

65| Mix the transcription/translation solution with $39 \mu \mathrm{L} 1 \times$ reporter lysis buffer and $50 \mu \mathrm{l}$ assay $2 \times$ buffer containing $o$-nitrophenyl $\beta$-galactoside of the $\beta$-galactosidase assay system.

66| Incubate the resulting solution in a 96 -well plate for $1 \mathrm{~h}$ at $37^{\circ} \mathrm{C}$.

67| Read the absorbance at $405 \mathrm{~nm}$ with a multilabel counter (Wallac 1420), and take a photographic image of each sample.

\section{? TROUBLESHOOTING}

Troubleshooting advice can be found in Table 1.

TABLE 1 | Troubleshooting table.

\begin{tabular}{|c|c|c|c|}
\hline Step & Problem & Possible reason & Solution \\
\hline $\begin{array}{l}19,21,22, \\
24,47,67\end{array}$ & Low signal intensity & Mis-handling of the translation medium & $\begin{array}{l}\text { Handle the translation solution on ice and } \\
\text { avoid vortexing. When mixing the solution, } \\
\text { use gentle taps or pipetting }\end{array}$ \\
\hline
\end{tabular}

Wrong translation medium possibly owing to damage during storage

Wrong MB-mRNA probe owing to mistranscription or damage during storage

Probe in high excess of the target. As the probe retains a target-independent translation activity, a large excess amount of the probe lowers the sensitivity $\left(I_{\text {on }} / I_{\text {off }}\right)$
22,47
Low sequence
Poor RNase $\mathrm{H}$ activity selectivity
Contamination by MB-mRNA probes targeting different alleles
Try a standard protein translation in the medium. If this does not work, use a new one

Check the purity by denaturing agarose gel electrophoresis (formaldehyde, MOPS). When the purity is not good enough, prepare a new MB-mRNA probe by using a freshly prepared and isolated template double-stranded DNA (dsDNA) for transcription

Check the concentrations of target and probe carefully

Check the RNase $\mathrm{H}$ activity. If it does not work, use a new one

To prevent contamination of inadequate templates, use disposable filter tips for all PCRs and transcription reactions. Negative control without template is indispensable to check the contamination during the PCR step 

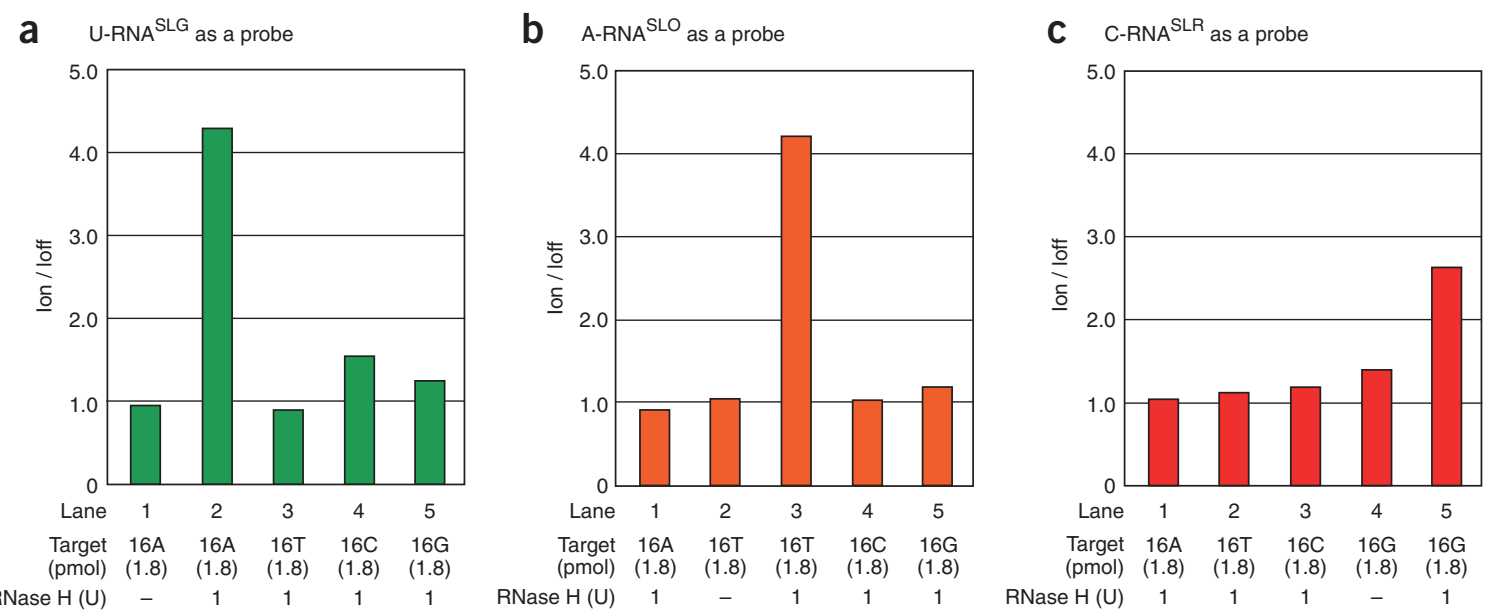

Figure 7 | RNase H-coupled sensing of targets $16 \mathrm{~A}, 16 \mathrm{~T}, 16 \mathrm{C}$ and $16 \mathrm{G}$ with (a) U-RNA ${ }^{\mathrm{SLG}}$, (b) A-RNA ${ }^{\mathrm{SLO}}$ or (c) C-RNA ${ }^{\text {SLR }}$ as a probe in $11 \mu$ l of a reconstituted translation medium after treatment with a luciferase assay solution.

\section{ANTICIPATED RESULTS}

\section{Steps 19, 21, 22 and 24}

As translation of reporter protein is not intended to be completely suppressed in the absence of target (see INTRODUCTION), it is most appropriate to refer to the on/off ratio of the chemiluminescence intensity $\left(I_{\text {on }}\right)$ in the presence of a particular target to that $\left(I_{\text {off }}\right)$ in its absence. Anticipated $I_{\text {on }} / I_{\text {off }}$ ratios are summarized in Figure 6 . In the absence of RNase $\mathrm{H}$, target $18 \mathrm{C}$ can be sensed by the full-match probe G-RNA ${ }^{\mathrm{BEST}}$ with $I_{\mathrm{on}} / I_{\text {off }}=3.1$ (lane 1 ). In the presence of RNase $\mathrm{H}$, the sensitivity becomes higher $\left(I_{\mathrm{on}} / I_{\text {off }}=6.2\right.$; lane 2$)$ with good discrimination of doubly mutated $\left(18 \mathrm{TA} ; I_{\mathrm{on}} / I_{\text {off }}=1.3\right.$; lane 3$)$ and singly A-mutated $\left(18 \mathrm{~A} ; I_{\text {on }} / I_{\text {off }}=1.7\right.$; lane 4$)$ targets. This is, however, not the case for singly T-mutated target $\left(18 \mathrm{~T} ; I_{\mathrm{on}} / I_{\text {off }}=4.3\right.$; lane 5$)$, which would form a relatively stable GT mismatch in the target-probe heteroduplex. The on/off ratio for target $18 \mathrm{C}$ becomes even more pronounced when using G-DNA ${ }^{\mathrm{BEST}}\left(I_{\text {on }} / I_{\text {off }}=12.5\right.$; lane 6$)$ in place of $\mathrm{G}-\mathrm{RNA}^{\mathrm{BEST}}\left(I_{\mathrm{on}} / I_{\text {off }}=6.2\right.$; lane 2$)$. The advantage of the RNase $\mathrm{H}$-coupled system can also be clearly demonstrated when using a smaller amount of target. Target $18 \mathrm{C}$ in $45 \mathrm{fmol}$ in $2.5 \mu \mathrm{l}$ of the medium $(18 \mathrm{nM})$ can scarcely be detected $\left(I_{\text {on }} / I_{\text {off }}=\right.$ 1.4; lane 7) in the absence of RNase $\mathrm{H}$, but in its presence it is readily sensed, with $I_{\text {on }} / I_{\text {off }}=3.8$ (lane 8 ), when a sensitive luminometer (Lumat LB 9507) is used. The detection limit with respect to full-match target 18C seems to lie in the range of $9 \mathrm{fmol}\left(I_{\text {on }} / I_{\text {off }}=1.7\right)$.

In the case of short $16-$ nt targets, even $16 \mathrm{C}\left(I_{\text {on }} / I_{\text {off }}=1.4\right.$; lane 9$)$, in addition to $16 \mathrm{~T}\left(I_{\text {on }} / I_{\text {off }}=0.94\right.$; lane 10$)$, cannot be sensed effectively in the absence of RNase $\mathrm{H}$. However, in the presence of the latter, the full-match $\mathrm{C}$-allele target gives rise to a significant signal enhancement $\left(I_{\text {on }} / I_{\text {off }}=5.7\right.$; lane 11$)$, whereas the T-mismatch remains inactive $\left(I_{\text {on }} / I_{\text {off }}=1.4\right.$; lane 12).

\section{Steps 47-49}

The chemiluminescence intensity $\left(I_{\text {on }}\right)$ for any mismatch target-probe combination - that is, 16A/A-RNA ${ }^{\text {SLO }}, 16 \mathrm{~A} / \mathrm{C}-\mathrm{RNA} \mathrm{A}^{\mathrm{SLR}}$,

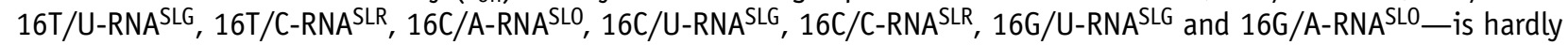

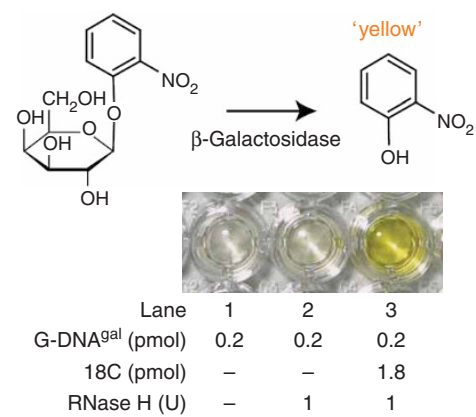

Figure 8 | RNase $\mathrm{H}$-coupled sensing of target $18 \mathrm{C}$ with G-DNA ${ }^{\text {gal }}$ as a probe in $11 \mu \mathrm{l}$ of a reconstituted translation medium after treatment with a $\beta$-galactosidase assay solution. Reaction scheme and photographic images of the assay solutions. distinguishable from that $\left(I_{\text {off }}\right)$ in the absence of target $\left(I_{\text {on }} / I_{\text {off }} \cong 1\right.$ in most cases $)$. On the other hand, matched target/probe combinations, that is, 16A/U-RNA ${ }^{S L G}$ and $16 \mathrm{~T} / \mathrm{A}-\mathrm{RNA}^{\mathrm{SLO} 0}\left(I_{\text {on }} / I_{\text {off }} \cong 4\right)$ and $16 \mathrm{G} / \mathrm{C}-\mathrm{RNA}^{\mathrm{SLR}}\left(I_{\text {on }} / I_{\text {off }} \cong 3\right)$, give rise to higher signal intensities, as shown in Figure 7. Thus, any probe sensitively responds to its partner target on a complementarity basis.

\section{Step 67}

The anticipated target-on/target-off ratio of the absorbance at $405 \mathrm{~nm}$ with RNase $\mathrm{H}$ is $I_{\text {on }} / I_{\text {off }}=12.6$ (Fig. 6, lane 13). $o$-Nitrophenol formed can be easily detected even visually (Fig. 8). 
ACKNOWLEDGMENTS We thank Drs. T. Kanamori and Y. Shimizu of the University of Tokyo for their kind advice and technical support. This work was supported by the Industrial Technology Research Grant Program of the New Energy and Industrial Technology Development Organization (NEDO) of Japan (S.S.) and by the Grant-inAid for Scientific Research (KAKENHI) in Priority Area "Molecular Nano Dynamics" (no. 17034026 for Y.A.) from the Ministry of Education, Culture, Sports, Science and Technology, Japan. We thank Toyobo Co. Ltd. for technical advice.

COMPETING INTERESTS STATEMENT The authors declare competing financial interests (see the HTML version of this article for details).

Published online at http://www.natureprotocols.com

Reprints and permissions information is available online at http://npg.nature.com/ reprintsandpermissions

1. Nakatani, K. Chemistry challenges in SNP typing. Chembiochem 5, 1623-1633 (2004).

2. Silverman, A.P. \& Kool, E.T. Quenched probes for highly specific detection of cellular RNAs. Trends Biotechnol. 23, 225-230 (2005).

3. Tyagi, S. \& Kramer, F.R. Molecular beacons: probes that fluoresce upon hybridization. Nat. Biotechnol. 14, 303-308 (1996).

4. Stojanovic, M.N., de Prada, P. \& Landry, D.W. Catalytic molecular beacons. Chembiochem 2, 411-415 (2001).

5. Hartig, J.S., Grune, I., Najafi-Shoushtari, S.H. \& Famulok, M. Sequence-specific detection of MicroRNAs by signal-amplifying ribozymes. J. Am. Chem. Soc. 126 , 722-723 (2004).

6. Sando, S., Sasaki, T., Kanatani, K. \& Aoyama, Y. Amplified nucleic acid sensing using programmed self-cleaving DNAzyme. J. Am. Chem. Soc. 125, 15720-15721 (2003).

7. Saghatelian, A., Guckian, K.M., Thayer, D.A. \& Ghadiri, M.R. DNA detection and signal amplification via an engineered allosteric enzyme. J. Am. Chem. Soc. 125, 344-345 (2003).

8. Pavlov, V., Shlyahovsky, B. \& Willner, I. Fluorescence detection of DNA by the catalytic activation of an aptamer/thrombin complex. J. Am. Chem. Soc. 127, 6522-6523 (2005).

9. Abe, H. \& Kool, E.T. Destabilizing universal linkers for signal amplification in self-ligating probes for RNA. J. Am. Chem. Soc. 126, 13980-13986 (2004).

10. Cai, J., Li, X., Yue, X. \& Taylor, J.S. Nucleic acid-triggered fluorescent probe activation by the Staudinger reaction. J. Am. Chem. Soc. 126, 16324-16325 (2004).

11. Fan, C., Plaxco, K.W. \& Heeger, A.J. Electrochemical interrogation of conformational changes as a reagentless method for the sequence-specific detection of DNA. Proc. Natl. Acad. Sci. USA 100, 9134-9137 (2003).
12. Patolsky, F., Weizmann, Y., Katz, E. \& Willner, I. Magnetically amplified DNA assays (MADA): sensing of viral DNA and single-base mismatches by using nucleic acid modified magnetic particles. Angew. Chem. Int. Ed. Engl. 42, 2372-2376 (2003).

13. Sando, S., Narita, A., Abe, K. \& Aoyama, Y. Doubly catalytic sensing of HIV-1-related CCR5 sequence in prokaryotic cell-free translation system using riboregulator-controlled luciferase activity. J. Am. Chem. Soc. 127, 5300-5301 (2005).

14. Brantl, S. Antisense-RNA regulation and RNA interference. Biochim. Biophys. Acta 1575, 15-25 (2002).

15. Isaacs, F.J. et al. Engineered riboregulators enable post-transcriptional control of gene expression. Nat. Biotechnol. 22, 841-847 (2004).

16. Mertens, N., Remaut, E. \& Fiers, W. Increased stability of phage T7g10 mRNA is mediated by either a $5^{\prime}$ - or a $3^{\prime}$-terminal stem-loop structure. Biol. Chem. 377 , 811-817 (1996).

17. Rosi, N.L. \& Mirkin, C.A. Nanostructures in biodiagnostics. Chem. Rev. 105, 1547-1562 (2005).

18. Breaker, R.R. Natural and engineered nucleic acids as tools to explore biology. Nature 432, 838-845 (2004).

19. Mummidi, S., Ahuja, S.S., McDaniel, B.L. \& Ahuja, S.K. The human CC chemokine receptor 5 (CCR5) gene. Multiple transcripts with $5^{\prime}$-end heterogeneity, dual promoter usage, and evidence for polymorphisms within the regulatory regions and noncoding exons. J. Biol. Chem. 272, 30662-30671 (1997).

20. Bhaumik, S. \& Gambhir, S.S. Optical imaging of Renilla luciferase reporter gene expression in living mice. Proc. Natl. Acad. Sci. USA 99, 377-382 (2002).

21. Nakajima, Y., Kimura, T., Suzuki, C. \& Ohmiya, Y. Improved expression of novel red- and green-emitting luciferases of Phrixothrix railroad worms in mammalian cells. Biosci. Biotechnol. Biochem. 68, 948-951 (2004).

22. Nakajima, Y., Ikeda, M., Kimura, T., Honma, S., Ohmiya, Y. \& Honma, K. Bidirectional role of orphan nuclear receptor ROR $\alpha$ in clock gene transcriptions demonstrated by a novel reporter assay system. FEBS Lett. 565, 122-126 (2004).

23. Viviani, V.R., Bechara, E.J. \& Ohmiya, Y. Cloning, sequence analysis and expression of active Phrixothrix railroadworms luciferases: relationship between bioluminescence spectra and primary structures. Biochemistry 38, 8271-8279 (1999).

24. Duck, P., Alvarado-Urbina, G., Burdick, B. \& Collier, B. Probe amplifier system based on chimeric cycling oligonucleotides. BioTechniques 9, 142-148 (1990).

25. Narita, A., Ogawa, K., Sando, S. \& Aoyama, Y. Visible sensing of nucleic acid sequences with a genetically encodable unmodified RNA probe. Angew. Chem. Int. Ed. Engl. 45, 2879-2883 (2006).

26. Shimizu, Y. et al. Cell-free translation reconstituted with purified components. Nat Biotechnol. 19, 751-755 (2001). 